\title{
Macrophage Activation Syndrome in Autoimmune Disease
}

\author{
Sean Deane ${ }^{\mathrm{a}}$ Carlo Selmi $^{\mathrm{b}}$ Suzanne S. Teuber ${ }^{\mathrm{a}}$ M. Eric Gershwin ${ }^{\mathrm{a}}$ \\ aDivision of Rheumatology, Allergy and Clinical Immunology, University of California, Davis, Calif., USA; \\ ${ }^{b}$ Department of Internal Medicine, IRCCS Istituto Clinico Humanitas, University of Milan, Rozzano, Italy
}

\section{Key Words}

Autoimmune responses - Autoimmunity ·

Hemophagocytic syndromes - Juvenile idiopathic arthritis • Lymphohistiocytosis · Macrophage activation syndrome • Macrophages

\begin{abstract}
Macrophage activation syndrome (MAS) is a phenomenon characterized by cytopenia, organ dysfunction, and coagulopathy associated with an inappropriate activation of macrophages. Current diagnostic criteria are imprecise, but the syndrome is now recognized as a form of hemophagocytic lymphohistiocy tosis that is characteristically associated with autoimmune diatheses. The diagnosis of incipient MAS in patients with autoimmune disease requires a high index of suspicion, as several characteristics of the disorder may be present in the underlying condition or infectious complications associated with the treatment thereof. Proposed treatment regimens include aggressive approaches that require validation in future controlled studies. This review discusses the major aspects of the pathophysiology, diagnosis, and management of MAS with a focus on the association with autoimmune disease.

Copyright $\odot 2010$ S. Karger AG, Basel
\end{abstract}

\section{Introduction}

The central role of macrophage activation in a hemophagocytic syndrome associated with pediatric rheumatic diseases was reported in 1985 [1], although the first descriptions of the disorder may have been as early as the mid-1970s [2, 3]. Subsequent work on the clinical entity now known as macrophage activation syndrome (MAS) has demonstrated that it may be appropriate to classify MAS as a secondary form of hemophagocytic lymphohistiocytosis (HLH). In this review, we will discuss aspects of the pathophysiology, diagnosis, and contemporary management of MAS/secondary HLH with a focus on associations with rheumatologic disease, and will accordingly examine the published literature using the MAS terminology with forays as appropriate into the literature accompanying HLH.

\section{Case Definition and Epidemiology}

MAS is a phenomenon characterized by cytopenia, organ dysfunction, and coagulopathy associated with inappropriate activation of macrophages. The current clas-

\section{KARGER}

Fax +4161306 1234 E-Mail karger@karger.ch www.karger.com
Correspondence to: Dr. M. Eric Gershwin

Division of Rheumatology, Allergy and Clinical Immunology

University of California at Davis, GBSF suite 6510

451 East Health Sciences Drive, Davis, CA 95616 (USA)

Tel. +1 530752 2884, Fax +1 530752 4669, E-Mail megershwin@ucdavis.edu 
Table 1. 2004 Criteria for the diagnosis of $\operatorname{HLH}[5,60]$

\begin{tabular}{l} 
Molecular diagnosis consistent with $\mathrm{HLH}$ or five of the eight fol- \\
lowing criteria \\
\hline Fever \\
Splenomegaly \\
Peripheral cytopenia in 2 or more lineages \\
$\quad \mathrm{Hb}<10.0 \mathrm{~g} / \mathrm{dl}(\mathrm{or} 9.0 \mathrm{~g} / \mathrm{dl}$ in infants $<4$ weeks) \\
$\quad$ Platelets $<100 \times 10^{6} / \mu \mathrm{l}$ \\
Neutrophils $<1.0 \times 10^{6} / \mu \mathrm{l}$ \\
Hypertriglyceridemia $\mathrm{r}$ hypofibrinogenemia \\
Triglycerides $\geq 265 \mathrm{mg} / \mathrm{dl}$ \\
Fibrinogen $\leq 150 \mathrm{mg} / \mathrm{dl}$ \\
Hemophagocytosis \\
$\quad$ Bone marrow \\
$\quad$ Spleen \\
$\quad$ Lymph node \\
CSF \\
Low or absent NK-cell activity \\
Ferritin $\geq 500 \mu \mathrm{g} / \mathrm{dl}$ \\
Soluble CD $25 \geq 2,400 \mathrm{U} / \mathrm{ml}$ \\
\hline
\end{tabular}

sification of MAS is imprecise, however, it is included among the reactive hemophagocytic syndromes, and the case definition generally proceeds according to the revised diagnostic criteria for HLH (table 1) $[4,5]$. The term 'macrophage activation syndrome' was used in a description of the disorder by Albert et al. [6] in 1992 and furthered by Stephan et al. [7, 8] in their 1993 description of 4 pediatric patients suffering from the disorder as a complication of autoimmune disease characterized by a proinflammatory milieu $[9,10]$. This terminology remains prevalent in the rheumatology literature, whereas syndromes described in the hematology and infectious disease literature often describe a similar phenomenon as secondary HLH [11]. It is now recognized that MAS is a form of secondary HLH. Some authors suggest that the terms are interchangeable [12-15], whereas others describe MAS as a distinct subset of secondary HLH [16, 17], and still others highlight the heterogeneity of disorders described by both terms and call for revised terminology based more precisely on pathophysiology [18-20].

Accordingly, the current diagnostic scheme remains a work in progress, and several groups have emphasized challenges in applying the most recent classification criteria for HLH to MAS. For example, systemic juvenile idiopathic arthritis (sJIA) is among the most frequent rheumatologic associations with MAS [20, 21]. However, sJIA is independently associated with anemia and hyperferritinemia [22] in the absence of MAS, and frequently
Table 2. Proposed criteria for the diagnosis of MAS complicating sJIA (at least two criteria must be fulfilled)

\begin{tabular}{lll}
\hline Laboratory criteria & Value \\
\hline $\begin{array}{l}\text { Relative decrease in platelet count } \\
\text { Elevations in aspartate aminotransferase }\end{array}$ & $\begin{array}{l}\leq 262 \times 10^{6} / \mu \mathrm{l} \\
\text { Decreased leukocyte count } \\
\text { Hypofibrinogenemia }\end{array}$ & $\begin{array}{l}\leq 4.0 \times 10^{6} / \mu \mathrm{l} \\
\leq 250 \mathrm{mg} / \mathrm{dl}\end{array}$ \\
\hline Clinical criteria & Manifestation \\
\hline Central nervous & $\begin{array}{l}\text { irritability } \\
\text { system dysfunction }\end{array}$ & $\begin{array}{l}\text { headache } \\
\text { lethargy } \\
\text { disorientation }\end{array}$ \\
& $\begin{array}{l}\text { seizures } \\
\text { coma }\end{array}$ \\
\hline Hemorrhages & $\begin{array}{l}\text { ecchymoses } \\
\text { purpura } \\
\end{array}$ & mucosal bleeding \\
\hline Hepatomegaly & $\geq 3$ cm below the costal margin \\
\hline
\end{tabular}

is associated with leukocytosis [23]. Each of these features is relevant to the HLH-2004 diagnostic criteria, and the overlap in clinical features can contribute to difficulty in recognizing the onset of MAS [24]. Similarly, coagulopathies are common in MAS and other disorders in the differential diagnosis for $\mathrm{HLH}$, thereby complicating attempts at obtaining tissue samples for histological diagnosis that may even then be prone to sampling error and a lack of specificity $[25,26]$.

To address these concerns and further refine the definition and classification of the disorder in the subset of patients with sJIA-associated MAS, Ravelli et al. [27] examined historical data from 74 patients with presumed MAS and 37 control patients with sJIA and high disease activity. Using a 'classification criteria approach', the authors proposed a set of four laboratory criteria and three clinical criteria for the diagnosis of MAS complicating sJIA (table 2). In their systemic evaluation, Ravelli et al. [27] also identified a number of characteristic findings on routinely available studies that, while not included in the formal proposed criteria, are associated with the syndrome and may contribute to the index of suspicion (table 3).

These criteria await prospective validation, and the degree to which they might be predictive in MAS associated with rheumatologic disorders other than MAS is unclear. For example, the same group later reported on historical data from pediatric patients suffering from MAS 
associated with systemic lupus erythematosus (SLE). They found that while MAS associated with SLE shared many clinical characteristics with sJIA-associated MAS, the differences were sufficient to render the proposed sJIA-associated MAS criteria inapplicable to SLE-associated MAS [20].

The epidemiology of MAS in autoimmune diseases [28-30] remains an open question in many cases. To date, the syndrome has been best studied in sJIAs, with estimates of clinically apparent MAS ranging from 7 to $13 \%$ $[24,31]$. Furthermore, subclinical marrow evidence of MAS was present in $>50 \%$ of patients with sJIA in one series [24]. However, MAS has been reported in a wide spectrum of rheumatologic disorders, from the primarily pediatric disorder of Kawasaki disease to the seronegative spondyloarthropathies in adults (table 4).

Comprehensive published data on MAS in other autoimmune disorders [32] are often lacking, and the calculation of quantitative estimates of the incidence and prevalence of MAS is further complicated by an evolving nomenclature and the heretofore prominent absence of clearly defined diagnostic criteria $[14,20,23]$. In the case of sJIA and Still's disease, it has been proposed that MAS is not a distinct disorder but comprises one end of a spectrum of disease activity $[24,33]$.

\section{Pathophysiology}

Microscopic descriptions of erythrophagocytosis by reticular macrophages in hemophagocytic syndromes were reported at least as early as 1939 [34]. Despite 70 years of study, however, the pathophysiology of MAS and other hemophagocytic syndromes remains poorly understood, and much of the understanding of MAS derives from the HLH literature [14].

\section{Overview of Macrophage Activation}

Not surprisingly, high levels of several T-cell-driven macrophage-stimulatory chemokines and cytokines may be found in hemophagocytic syndromes, including IFN$\gamma, \mathrm{MCP}-1$, and M-CSF [35-38]. The central role of T cells in the hemophagocytic disorders is further illustrated by the diagnostic and prognostic significance of elevated serum levels of the IL-2 receptor, CD25 [39]. Conversely, elevated levels of several macrophage-driven proinflammatory cytokines are present in many cases, including IL-6, IL-12, IL-18, and TNF- $\alpha[37,40,41]$, and the pres-
Table 3. Laboratory features not included among diagnostic criteria characterizing MAS complicating sJIA [27]

\begin{tabular}{lll}
\hline & Sensitivity & Specificity \\
\hline ESR $\leq 50 \mathrm{~mm} / \mathrm{h}$ & 0.79 & 0.8 \\
Alanine aminotransferase $\geq 40 \mathrm{U} / \mathrm{l}$ & 0.81 & 0.91 \\
Bilirubin $\geq 1.2 \mathrm{mg} / \mathrm{dl}$ & 0.75 & 1 \\
Lactate dehydrogenase $\geq 900 \mathrm{U} / \mathrm{l}$ & 0.75 & 0.93 \\
Albumin $\leq 2.5 \mathrm{~g} / \mathrm{l}$ & 0.35 & 0.95 \\
Serum sodium $\leq 130 \mathrm{mEq} / \mathrm{l}$ & 0.67 & 1
\end{tabular}

Table 4. Autoimmune diseases for which an association with MAS has been reported

\begin{tabular}{ll}
\hline Autoimmune diseases & References \\
\hline Dermatomyositis & 85 \\
Kawasaki disease & $44,86,87$ \\
SLE & $20,44,57,86,88-92$ \\
Adult-onset Still's disease & 93 \\
Ankylosing spondylitis & 94 \\
Sarcoidosis & 95 \\
Inflammatory bowel disease & 96,97 \\
Enthesitis-related arthritis & 31 \\
Undefined autoimmune disease & 57 \\
Polyarticular JIA & 98 \\
sJIA/Still's disease & $8,14,15,31,33,40,44,50$, \\
& $53,57,75,93,99-109$ \\
\hline
\end{tabular}

ence of TNF- $\alpha$ and IL- 6 expression by CD68+ macrophages has been demonstrated in the hepatic parenchyma of patients with hemophagocytic syndromes [42]. The role of IL-1 is less clear in hemophagocytic syndromes, being elevated in some cases and normal in others, perhaps reflecting heterogeneity in the disorders [37, 43]. Striking proliferation of CD163+ hemophagocytic macrophages in marrow and lymphoid tissues is a central feature of hemophagocytic disorders [44, 45]. The literature suggests that these cells may not be the antigen-presenting cells (APCs) responsible for initiating the syndrome [15].

Intriguingly, CD163 is associated with the 'alternate' pathway of macrophage differentiation, traditionally leading to an anti-inflammatory phenotype [46]. Perhaps counterintuitively, a subgroup of patients with sJIA patients at higher presumed risk for MAS were found to express higher levels of genes associated with negative feedback regulation of inflammation [47]. The authors specu- 
Table 5. Established genetic causes for familial HLH

\begin{tabular}{ll}
\hline Genetic causes & References \\
\hline $\begin{array}{l}\text { Monogenic defects in familial HLH } \\
\text { Perforin mutations }\end{array}$ & 49 \\
Syntaxin-11 & 110 \\
MUNC13-4 abnormalities & $52,53,110,111$ \\
\hline Monogenic periodic fever syndromes & \\
CINCA/NOMID syndrome & 31 \\
Hyper-IgD syndrome & 38 \\
\hline Monogenic primary immunodeficiencies & \\
Griscelli syndrome & 112 \\
X-linked lymphoproliferative disease & 60,68 \\
Immunodeficiency, centromeric region & \\
$\quad$ instability, and facial anomalies & 113 \\
Adenosine deaminase deficiency & 114 \\
Chediak-Higashi syndrome & 115 \\
Hermansky-Pudlak syndrome (type II) & 116 \\
\hline
\end{tabular}

late that inflammation initiated by Toll-like receptor activation events and characterized by expression of IL-1 and IL-6 may lead to negative feedback responses that direct macrophages to a CD163+ 'scavenger' phenotype, priming the progression to the clinically apparent hemophagocytic syndromes [47]. A separate group demonstrated that the anti-inflammatory molecule $\mathrm{HO}-1$ is strongly associated with CD163 expression and hemophagocytosis in macrophages, and may serve a protective role in sepsis [25]. Furthermore, elevated levels of the immunomodulatory cytokine IL-10 have been identified in patients with HLH [41]. Taken together, these data beg the question of whether CD163+ erythrophagocytic macrophages actually represent an effector arm of a counterregulatory response to inflammation in the hemophagocytic syndromes $[14,15]$.

\section{Natural Killer Cell and Cytotoxic CD8+ T-Cell Defects}

Studies of patients with familial forms of HLH demonstrated that diminished cytotoxicity of CD8+ T cells as well as natural killer (NK) cells were central features of those disorders [48]. Subsequently, single gene defects in perforin expression were found to be causative of many cases of the familial forms of HLH [49]. Additionally, recent data have suggested that heterozygotic polymorphisms in perforin genes may be associated with the development of MAS in patients with coexistent sJIA. At least three genes have been identified as causative in familial HLH, while several monogenic disorders and primary immunodeficiencies associated with defective cytotoxic function may present with hemophagocytic syndromes as a primary manifestation of the underlying molecular defect (table 5).

Extension of these data to MAS confirmed that diminished NK-cell activity was strongly associated with the development of MAS in sJIA $[18,19]$. Even in the absence of clinical MAS, defects in both CD8+ cytotoxic function and NK-cell function can distinguish sJIA from other rheumatologic syndromes in the JIA classification scheme of the International League of Associations for Rheumatology that are far less commonly associated with MAS [50, 51]. Interestingly, it has now been recognized that polymorphisms in some of the genes associated with familial hemophagocytosis syndromes may also be associated with the development of MAS in sJIA $[52,53]$.

\section{Current Pathophysiologic Understanding}

Elucidation of the cytokine milieu associated with hemophagocytic syndromes, together with the identification of associated defects in T- and NK-cell cytotoxicity, have contributed to two models of the pathogenesis of MAS. In the first model, defective clearance of infected cells leads to ongoing antigen presentation by APCs, leading to dysregulated activation of T cells and macrophages and the subsequent manifestations of the disorder [54]. In the second model, defects in the cytotoxic response result in a failure to clear the APCs and activated T cells themselves, inducing the persistence of activated immune cells that would otherwise be eliminated through cytotoxic mechanisms for immune downregulation or tolerance $[4,14,15,54,55]$. While there is some evidence for both models, no identified infectious trigger can be found in many patients. Additionally, the finding that G-CSF worsens while cyclosporine improves the syndrome more strongly supports the second hypothesis [54].

\section{Additional Clinical Features}

\section{Recognition of MAS in Rheumatologic Disease}

The recognition of incipient MAS in patients with rheumatologic disease requires a high index of suspicion, as several characteristics of the disorder may be shared with underlying autoimmune diseases, such as cytopenia 
Table 6. Presumed precipitating factors in secondary HLH

\begin{tabular}{|c|c|}
\hline Precipitating factors & References \\
\hline \multicolumn{2}{|l|}{ Medications } \\
\hline Aspirin & 57 \\
\hline Non-steroidal anti-inflammatory drugs & 1,117 \\
\hline Sulfasalazine & 57 \\
\hline Etanercept & $2,3,106$ \\
\hline Anakinra & 74 \\
\hline Gold salts & $1,7,118$ \\
\hline Morniflumate & 57 \\
\hline Methotrexate & $105,119,120$ \\
\hline Infliximab & 96 \\
\hline Penicillamine & 121 \\
\hline Vancomycin & 122 \\
\hline Autologous stem cell transplantation & $123-125$ \\
\hline Parenteral lipid administration & 126 \\
\hline \multicolumn{2}{|l|}{ Infectious agents } \\
\hline Epstein-Barr virus & 57,127 \\
\hline Cytomegalovirus & 18,19 \\
\hline Varicella virus & 57 \\
\hline HHV6 & 128 \\
\hline Parvovirus B19 & 57 \\
\hline Hepatitis A & 129 \\
\hline HIV/AIDS & 33 \\
\hline Adenovirus & 130 \\
\hline Coxsackievirus & 57 \\
\hline Torovirus & 44 \\
\hline Escherichia coli & 44 \\
\hline Salmonella & 57 \\
\hline Enterococcus & 31 \\
\hline Tuberculosis & 131 \\
\hline Visceral leishmaniasis & 20,132 \\
\hline Pneumocystis jiroveci & 57 \\
\hline
\end{tabular}

and CNS dysfunction in SLE or hyperferritinemia in sJIA [23]. Furthermore, the clinical presentation of MAS may strongly resemble overwhelming infection and sepsis, the latter of which is both a more common condition and one to which patients already on immunosuppressive therapies may be predisposed [56]. The presence of factors suspected to be associated with MAS (table 6) may provide clues to the disorder, but in some cases, no antecedent trigger can be identified [57].

Therefore, while MAS should be considered in the differential diagnosis of all patients with rheumatologic disease and a change in their baseline consistent with the clinical features of the disease, the entirety of the individual clinical presentation must be taken into account in assessing the pretest probability of the disorder.

In a large review of 74 sJIA patients by Ravelli et al. [27], the onset of fever $>38^{\circ} \mathrm{C}$ was the most common but
Table 7. Prevalence of clinical features associated with MAS complicating sJIA $[1-3,7,8,27,100,103,117,118,121,125,133-146]$

\begin{tabular}{lll}
\hline Clinical features & $\begin{array}{l}\text { Patients } \\
\text { positive, } n\end{array}$ & $\begin{array}{l}\text { Prevalence in } \\
\text { reported analyses }\end{array}$ \\
\hline Fever $\geq 38^{\circ} \mathrm{C}$ & 60 & 0.81 \\
Hepatomegaly & 45 & 0.61 \\
Cutaneous rash & 33 & 0.45 \\
Splenomegaly & 33 & 0.45 \\
Hemorrhages & 29 & 0.39 \\
CNS dysfunction & 28 & 0.38 \\
Lymphadenopathy & 21 & 0.28 \\
\hline
\end{tabular}

least specific finding. However, the authors comment that the specificity data regarding fever may be misleading, as changes in the fever pattern from the spiking pattern typical of sJIA to the nonremitting pattern of MAS may provide additional information to guide the index of suspicion. The potential for clinical heterogeneity in the disorder is highlighted by the fact that less than a third of the patients in this series exhibited detectable lymphadenopathy (table 7).

Hepatomegaly was present in just over $60 \%$ of the patients with the disorder, with other features such as a cutaneous rash, bleeding diatheses, splenomegaly, and CNS dysfunction all being present in less than half of the patients. Stephan et al. [57] reported on 24 patients with a range of rheumatic diseases complicated by MAS, some of whom were included in the Ravelli series. Half of the children in their series had pulmonary involvement, and $>40 \%$ required admission to the intensive care unit. Organ involvement further extended to cardiac dysfunction in $42 \%$ of patients and renal involvement in $16 \%$.

Of the nine possible HLH-2004 criteria for MAS, three involve tests (sCD25, NK cell activity assays, and genetic testing) $[58,59]$ that are unlikely to be rapidly available in-house at many institutions, while a fourth requires both the ability to undergo an invasive procedure and the avoidance of sampling error [5, 27, 60]. Furthermore, even the finding of hemophagocytosis by CD163+ macrophages in marrow and other tissue is not unique to the HLH disorders [25]. Thus, routine testing of all patients with rheumatologic disease and a new clinical feature (such as fever) for each of the HLH-2004 criteria would be cost-ineffective, could confuse the diagnosis if biopsy data were misapplied in isolation, and might expose many patients to unnecessary risks. Similarly, waiting for the delayed results of HLH-2004-directed testing in pa- 
Table 8. Treatment options proposed for HLH associated with autoimmune disease in case series and individual reports

\begin{tabular}{ll}
\hline Therapy & References \\
\hline Cyclosporine & $7,8,31,57,147$ \\
Etanercept & 56,143 \\
Anakinra & 43 \\
Intravenous immunoglobulin & $33,75,108,109,130$ \\
Etoposide & $5,60,67,71,100,148$ \\
Plasmapheresis & 149 \\
Abatacept & 61 \\
Antithymocyte globulin & $7,8,61$ \\
Corticosteroids & $7,8,12,150$ \\
Naproxen & 150 \\
Splenectomy & 151 \\
\hline
\end{tabular}

tients with true MAS prior to initiating therapy could invite catastrophe $[17,23]$, and many patients with true MAS may require treatment initiation prior to the fulfillment of strict criteria when clinical suspicion is high [61], similar to aggressive forms of arthritis [32,62] due to novel mechanisms $[63,64]$. Lastly, differences in precipitating events, diagnostic parameters, and prognostic factors between adults and children exist [65-72], leading some authors to suggest that the current gold standard of the HLH-2004 criteria cannot be applied in the adult population [12].

Given the problems of using delayed results to diagnose a fulminant disease, together with both the poor individual sensitivity and specificity of many of the clinical findings of MAS according to the HLH-2004 criteria, certain features on routine laboratories may be of greater utility at the bedside in the initial consideration of the disorder. Indeed, the proposed Ravelli criteria for MAS complicating sJIA use laboratory values that can be quickly obtained locally at inpatient institutions with reasonably equipped laboratory facilities. However, the Ravelli criteria are to date neither validated in sJIA nor intended to apply to MAS in other disorders [20]. Furthermore, the problem of overlap of individual signs and symptoms with other rheumatologic conditions remains [27].

Grom [54] and others [23, 57, 73, 74] have suggested that the characteristically low erythrocyte sedimentation rate (ESR) in MAS may provide a valuable signal to distinguish the onset of MAS (in which the ESR falls despite worsening inflammation) from worsening of inflammation in other disorders that can be confused with MAS, but typically would manifest in the opposite change in the ESR. Ferritin, one of the HLH-2004 diagnostic criteria, is widely available in many diagnostic laboratories and has been suggested as an inexpensive first step in a diagnostic screening strategy capable of being widely applied to exclude a hemophagocytic syndrome in adult patients presenting with the systemic inflammatory response syndrome [12]. The authors propose the measurement of serum ferritin as a 'gateway' test to guide the rational application of more specialized diagnostic procedures and the rapid administration of therapy $[12,33$, 75].

\section{Treatment Considerations}

No standard of care yet exists for the diagnosis and treatment of MAS in many patients with rheumatologic disease $[12,27]$, similar to what is observed in other forms of autoimmunity [76-78]. Case series and individual reports supporting the use of a number of immunosuppressive regimens for hemophagocytic syndromes abound in the literature (table 8).

Interpretation of the collective data is complicated by the fact that a number of the therapies described have also been implicated as potential precipitants of the hemophagocytic syndromes (table 6), and the possibility that development of presumed drug-related MAS in some patients may represent insufficient control of the underlying inflammation rather than a true drug-related event $[23,54,79]$.

In 2002, Henter et al. [65] published a report demonstrating an $80 \%$ survival rate to hematopoietic stem cell transplants compared to approximately $50 \%$ survival in historical controls using the HLH-94 protocol. Building on this experience, the group [65] recently published widely accepted revised diagnostic and therapeutic guidelines for the management of children under 18 years suffering from any HLH form according to the experimental protocol of the ongoing HLH-2004 study [5, 60]. Notably, their treatment protocol recommends maximal supportive care prior to initiation of specific treatment. These measures are aggressive, and include the administration of empiric oral anti-fungal therapy, prophylactic cotrimoxazole, intravenous immunoglobulin, peptic ulcer prophylaxis, and, in patients with coexistent viral infections, consideration of specific antiviral therapy. Therapy is initiated and continued for an 8-week tapering course, with re-intensification of therapy to week-2 levels if reactivation develops (table 9). 
Table 9. The HLH-2004 treatment protocol for the management of familial and secondary HLH in children younger than 18 years $[5,60]$

\begin{tabular}{|c|c|c|c|}
\hline Systemic therapy & Dexamethasone & Etoposide & Cyclosporine \\
\hline Week 1 & $10 \mathrm{mg} / \mathrm{m}^{2}$ daily & $150 \mathrm{mg} / \mathrm{m}^{2}$ i.v. twice weekly & $3 \mathrm{mg} / \mathrm{kg}$ twice daily \\
\hline Week 2 & $10 \mathrm{mg} / \mathrm{m}^{2}$ daily & $150 \mathrm{mg} / \mathrm{m}^{2}$ i.v. twice weekly & dose to trough $200 \mu \mathrm{g} / \mathrm{l}$ \\
\hline Week 3 & $5 \mathrm{mg} / \mathrm{m}^{2}$ daily & $150 \mathrm{mg} / \mathrm{m}^{2}$ i.v. once weekly & dose to trough $200 \mu \mathrm{g} / \mathrm{l}$ \\
\hline Week 4 & $5 \mathrm{mg} / \mathrm{m}^{2}$ daily & $150 \mathrm{mg} / \mathrm{m}^{2}$ i.v. once weekly & dose to trough $200 \mu \mathrm{g} / \mathrm{l}$ \\
\hline Week 5 & $2.5 \mathrm{mg} / \mathrm{m}^{2}$ daily & $150 \mathrm{mg} / \mathrm{m}^{2}$ i.v. once weekly & dose to trough $200 \mu \mathrm{g} / \mathrm{l}$ \\
\hline Week 6 & $2.5 \mathrm{mg} / \mathrm{m}^{2}$ daily & $150 \mathrm{mg} / \mathrm{m}^{2}$ i.v. once weekly & dose to trough $200 \mu \mathrm{g} / \mathrm{l}$ \\
\hline Week 7 & $1.25 \mathrm{mg} / \mathrm{m}^{2}$ daily & $150 \mathrm{mg} / \mathrm{m}^{2}$ i.v. once weekly & dose to trough $200 \mu \mathrm{g} / \mathrm{l}$ \\
\hline Week 8 & taper and discontinue & $150 \mathrm{mg} / \mathrm{m}^{2}$ i.v. once weekly & dose to trough $200 \mu \mathrm{g} / \mathrm{l}$ \\
\hline Intrathecal therapy ${ }^{a}$ & $<1$ year of age & $1-2$ years of age & $2-3$ years of age \\
\hline Methotrexate & $6 \mathrm{mg}$ & $8 \mathrm{mg}$ & $10 \mathrm{mg}$ \\
\hline Prednisolone & $4 \mathrm{mg}$ & $6 \mathrm{mg}$ & $8 \mathrm{mg}$ \\
\hline
\end{tabular}

${ }^{\text {a }}$ CSF evaluation at diagnosis and after 14 days - if there is clinical neurologic progression or abnormal CSF at 2 weeks, intrathecal therapy should be given weekly on days 15, 22, 29, and 36.

If patients respond and there is no evidence of reactivation or a known familial HLH syndrome, a secondary form of HLH (such as autoimmune disease-associated MAS) is presumed, treatment is discontinued, and close follow-up is initiated. Where reactivation occurs or a genetic HLH syndrome is identified, continuation therapy is initiated and the patient proceeds to definitive therapy with hematopoietic stem cell transplant $[5,60]$.

However, application of the HLH-2004 protocol to secondary forms of HLH such as those due to malignancy or rheumatic disease may be imperfect, and the authors of the HLH-2004 guidelines concede that alternate treatment modalities may be required in these scenarios $[5,60]$, e.g. as many as half of the patients with MAS secondary to sJIA may respond to corticosteroids alone [23, $24,57]$. Additionally, the clinical features of MAS may differ from those seen in other forms of HLH [17, 31, 80, 81], and the features of HLH syndromes in children may differ from those in adults [12], potentially altering the risk/benefit ratio of therapies originally applied to familial and other forms of HLH.

In children, some authors have suggested risk stratification to guide approaches to initial therapy $[12,67,71]$. Similar data are not extant in adults, however [12]. Nevertheless, in both children and adults with MAS, some authors have advocated an approach centered on aggressive supportive management and high-dose corticosteroids as an initial step, followed by second-line therapies for refractory disease as indicated, such as cyclosporine A, etoposide, and the administration of intravenous immunoglobulin [12, 23]. A multinational (Canadian/ Swiss/French) group has advocated an approach in adults that includes initiation of high-dose corticosteroids, elimination of known or suspected triggers, initiation of aggressive supportive measures, and infection control, with progression in the face of refractory disease to either intravenous immunoglobulin ( $1 \mathrm{~g} / \mathrm{kg}$ for 2 days) or, in the case of malignancy or Epstein-Barr virus infection, either cyclosporine A/etoposide or appropriate chemotherapy [12]. In the event of refractory disease despite eventual progression to cyclosporine A/etoposide, the suggested protocol of Emmenegger et al. [12] allows for consideration of progression to such therapies as polychemotherapy, plasma exchange, antithymocyte globulin, splenectomy, or hematopoietic stem cell transplant.

\section{Conclusions}

MAS is a form of secondary HLH, the appropriate diagnosis and management of which have historically been clouded by an imperfect nomenclature and an immature but evolving understanding of the underlying pathophysiology. The history of the management of MAS associated with autoimmune diseases, together with associated HLH syndromes such as those that may accompany ma- 
lignancy, primary immunodeficiency, and infection, highlight the critical role of the clinical immunologist at the juncture of the traditional specialties of hematology/ oncology, allergy/immunology, infectious disease, rheumatology, and the subdivisions of adult and pediatric medicine thereof [82]. The modern management of MAS and other HLH syndromes has made great strides as a result of therapeutic advances over the last 20 years, similar to promising approaches to therapies [83] and etiology [84] in other clinical settings, but the promise of even greater strides looms as the benefits of standardized nomenclature, systematic investigation, and collaborative medicine take root in the soil of team-based science.

\section{References}

1 Hadchouel M, Prieur AM, Griscelli C: Acute hemorrhagic, hepatic, and neurologic manifestations in juvenile rheumatoid arthritis: possible relationship to drugs or infection. J Pediatr 1985;106:561-566.

-2 Ramanan AV, Schneider R: Macrophage activation syndrome following initiation of etanercept in a child with systemic onset juvenile rheumatoid arthritis. J Rheumatol 2003;30:401-403

3 Ramanan AV, Schneider R: Macrophage activation syndrome - what's in a name! J Rheumatol 2003;30:2513-2516.

-4 Filipovich AH: Hemophagocytic lymphohistiocytosis and related disorders. Curr Opin Allergy Clin Immunol 2006;6:410415.

5 Henter JI: Treatment protocol for hemophagocytic lymphohistiocytosis 2004. Stockholm, National Institutes of Health, 2009.

6 Albert A, Azgui Z, Buisine J, Ciaudo M, Fenneteau O, Fillola G, Lasserre M, Merle-Beral H, Mielot F, Raphael M: Macrophage activation syndromes. Nouv Rev Fr Hematol 1992; 34:435-441.

7 Stephan JL, Donadieu J, Ledeist F, Blanche S, Griscelli C, Fischer A: Treatment of familial hemophagocytic lymphohistiocytosis with antithymocyte globulins, steroids, and cyclosporin A. Blood 1993;82:2319-2323.

-8 Stephan JL, Zeller J, Hubert P, Herbelin C, Dayer JM, Prieur AM: Macrophage activation syndrome and rheumatic disease in childhood: a report of four new cases. Clin Exp Rheumatol 1993;11:451-456.

9 Barak V, Selmi C, Schlesinger M, Blank M, Agmon-Levin N, Kalickman I, Gershwin ME, Shoenfeld Y: Serum inflammatory cytokines, complement components, and soluble interleukin 2 receptor in primary biliary cirrhosis. J Autoimmun 2009;33:178-182.

10 Blank M, Gershwin ME: Autoimmunity: from the mosaic to the kaleidoscope. J Autoimmun 2008;30:1-4

11 Athreya BH: Is macrophage activation syndrome a new entity? Clin Exp Rheumatol 2002;20:121-123.
12 Emmenegger U, Schaer DJ, Larroche C, Neftel KA: Haemophagocytic syndromes in adults: current concepts and challenges ahead. Swiss Med Wkly 2005;135:299-314.

13 Ramanan AV, Baildam EM: Macrophage activation syndrome is hemophagocytic lymphohistiocytosis - need for the right terminology. J Rheumatol 2002;29:1105, author reply 1105

14 Behrens EM: Macrophage activation syndrome in rheumatic disease: what is the role of the antigen presenting cell? Autoimmun Rev 2008;7:305-308.

15 Behrens EM, Beukelman T, Gallo L, Spangler J, Rosenkranz M, Arkachaisri T, Ayala R, Groh B, Finkel TH, Cron RQ: Evaluation of the presentation of systemic onset juvenile rheumatoid arthritis: data from the Pennsylvania Systemic Onset Juvenile Arthritis Registry (PASOJAR). J Rheumatol 2008;35:343348.

16 Janka GE: Hemophagocytic syndromes. Blood Rev 2007;21:245-253.

17 Janka GE: Familial and acquired hemophagocytic lymphohistiocytosis. Eur J Pediatr 2007;166:95-109.

18 Grom AA: Macrophage activation syndrome and reactive hemophagocytic lymphohistiocytosis: the same entities? Curr Opin Rheumatol 2003:15:587-590.

19 Grom AA, Villanueva J, Lee S, Goldmuntz EA, Passo MH, Filipovich A: Natural killer cell dysfunction in patients with systemiconset juvenile rheumatoid arthritis and macrophage activation syndrome. J Pediatr 2003; 142:292-296.

20 Pringe A, Trail L, Ruperto N, Buoncompagni A, Loy A, Breda L, Martini A, Ravelli A: Macrophage activation syndrome in juvenile systemic lupus erythematosus: an under-recognized complication? Lupus 2007;16:587-592.

21 Berkun Y, Padeh S: Macrophage activation syndrome in juvenile idiopathic arthritis; in Shoenfeld Y, Cervera R, Gershwin ME (eds): Diagnostic Criteria in Autoimmune Diseases. Totowa, Humana Press, 2008, pp 21-24.

22 Recalcati S, Invernizzi P, Arosio P, Cairo G New functions for an iron storage protein: the role of ferritin in immunity and autoimmunity. J Autoimmun 2008;30:84-89.
23 Kelly A, Ramanan AV: Recognition and management of macrophage activation syndrome in juvenile arthritis. Curr Opin Rheumatol 2007;19:477-481.

24 Behrens EM, Beukelman T, Paessler M, Cron RQ: Occult macrophage activation syndrome in patients with systemic juvenile idiopathic arthritis. J Rheumatol 2007;34: 1133-1138

25 Schaer DJ, Schaer CA, Schoedon G, Imhof A, Kurrer MO: Hemophagocytic macrophages constitute a major compartment of heme oxygenase expression in sepsis. Eur J Haematol 2006;77:432-436.

26 Stabile A, Bertoni B, Ansuini V, La Torraca I, Salli A, Rigante D: The clinical spectrum and treatment options of macrophage activation syndrome in the pediatric age. Eur Rev Med Pharmacol Sci 2006;10:53-59.

-27 Ravelli A, Magni-Manzoni S, Pistorio A, Besana C, Foti T, Ruperto N, Viola S, Martini A: Preliminary diagnostic guidelines for macrophage activation syndrome complicating systemic juvenile idiopathic arthritis. J Pediatr 2005; 146:598-604.

28 Cooper GS, Bynum ML, Somers EC: Recent insights in the epidemiology of autoimmune diseases: improved prevalence estimates and understanding of clustering of diseases. J Autoimmun 2009;33:197-207.

29 Hudson M, Rojas-Villarraga A, Coral-Alvarado $\mathrm{P}$, Lopez-Guzman S, Mantilla RD, Chalem P, Baron M, Anaya JM: Polyautoimmunity and familial autoimmunity in systemic sclerosis. J Autoimmun 2008;31:156159.

30 Neuhausen SL, Steele L, Ryan S, Mousavi M, Pinto M, Osann KE, Flodman P, Zone JJ: Cooccurrence of celiac disease and other autoimmune diseases in celiacs and their firstdegree relatives. J Autoimmun 2008;31: 160-165.

31 Sawhney S, Woo P, Murray KJ: Macrophage activation syndrome: A potentially fatal complication of rheumatic disorders. Arch Dis Child 2001;85:421-426.

32 Durai M, Huang MN, Moudgil KD: Self heat-shock protein 65 -mediated regulation of autoimmune arthritis. J Autoimmun 2009;33:208-213. 
-33 Emmenegger U, Reimers A, Frey U, Fux C, Bihl F, Semela D, Cottagnoud P, Cerny A, Spaeth PJ, Neftel KA: Reactive macrophage activation syndrome: a simple screening strategy and its potential in early treatment initiation. Swiss Med Wkly 2002;132:230236.

-34 Scott RB, Robb-Smith AHB: Histiocytic medullary reticulosis. Lancet 1939;234:194198.

-35 Akashi K, Hayashi S, Gondo H, Mizuno S, Harada M, Tamura K, Yamasaki K, Shibuya T, Uike N, Okamura T, et al: Involvement of interferon-gamma and macrophage colonystimulating factor in pathogenesis of haemophagocytic lymphohistiocytosis in adults. $\mathrm{Br}$ J Haematol 1994;87:243-250.

-36 Hasegawa D, Kojima S, Tatsumi E, Hayakawa A, Kosaka Y, Nakamura H, Sako M, Osugi Y, Nagata S, Sano K: Elevation of the serum Fas ligand in patients with hemophagocytic syndrome and Diamond-Blackfan anemia. Blood 1998;91:2793-2799.

\37 Henter JI, Elinder G, Soder O, Hansson M, Andersson B, Andersson U: Hypercytokinemia in familial hemophagocytic lymphohistiocytosis. Blood 1991;78:2918-2922.

-38 Rigante D, Capoluongo E, Bertoni B, Ansuini V, Chiaretti A, Piastra M, Pulitano S, Genovese O, Compagnone A, Stabile A: First report of macrophage activation syndrome in hyperimmunoglobulinemia $\mathrm{D}$ with periodic fever syndrome. Arthritis Rheum 2007; 56:658-661.

39 Imashuku S, Hibi S, Sako M, Ishida Y, Mugishima $\mathrm{H}$, Chen J, Tsunematsu Y: Soluble interleukin-2 receptor: a useful prognostic factor for patients with hemophagocytic lymphohistiocytosis. Blood 1995;86:47064707.

40 Maeno N, Takei S, Imanaka H, Yamamoto K, Kuriwaki K, Kawano Y, Oda H: Increased interleukin-18 expression in bone marrow of a patient with systemic juvenile idiopathic arthritis and unrecognized macrophage-activation syndrome. Arthritis Rheum 2004;50: 1935-1938.

-41 Osugi Y, Hara J, Tagawa S, Takai K, Hosoi G, Matsuda Y, Ohta H, Fujisaki H, Kobayashi M, Sakata N, Kawa-Ha K, Okada S, Tawa A: Cytokine production regulating $\mathrm{Th} 1$ and Th2 cytokines in hemophagocytic lymphohistiocytosis. Blood 1997;89:4100-4103.

42 Billiau AD, Roskams T, Van Damme-Lombaerts R, Matthys P, Wouters C: Macrophage activation syndrome: characteristic findings on liver biopsy illustrating the key role of activated, IFN-gamma-producing lymphocytes and IL-6- and TNF-alpha-producing macrophages. Blood 2005;105:1648-1651.

43 Kelly A, Ramanan AV: A case of macrophage activation syndrome successfully treated with anakinra. Nat Clin Pract Rheumatol 2008;4:615-620.
44 Avcin T, Tse SM, Schneider R, Ngan B, Silverman ED: Macrophage activation syndrome as the presenting manifestation of rheumatic diseases in childhood. J Pediatr 2006;148: 683-686.

45 Schaer DJ, Schleiffenbaum B, Kurrer M, Imhof A, Bachli E, Fehr J, Moller HJ, Moestrup SK, Schaffner A: Soluble hemoglobin-haptoglobin scavenger receptor CD163 as a lineage-specific marker in the reactive hemophagocytic syndrome. Eur J Haematol 2005 74:6-10.

46 Porcheray F, Viaud S, Rimaniol AC, Leone C, Samah B, Dereuddre-Bosquet N, Dormont D, Gras G: Macrophage activation switching: an asset for the resolution of inflammation. Clin Exp Immunol 2005;142:481-489.

47 Fall N, Barnes M, Thornton S, Luyrink L, Olson J, Ilowite NT, Gottlieb BS, Griffin T, Sherry DD, Thompson S, Glass DN, Colbert RA, Grom AA: Gene expression profiling of peripheral blood from patients with untreated new-onset systemic juvenile idiopathic arthritis reveals molecular heterogeneity that may predict macrophage activation syndrome. Arthritis Rheum 2007;56:37933804.

48 Egeler RM, Shapiro R, Loechelt B, Filipovich A: Characteristic immune abnormalities in hemophagocytic lymphohistiocytosis. J Pediatr Hematol Oncol 1996;18:340-345.

-49 Stepp SE, Dufourcq-Lagelouse R, Le Deist F, Bhawan S, Certain S, Mathew PA, Henter JI, Bennett M, Fischer A, de Saint Basile G, Kumar V: Perforin gene defects in familial hemophagocytic lymphohistiocytosis. Science 1999;286:1957-1959.

50 Villanueva J, Lee S, Giannini EH, Graham TB, Passo MH, Filipovich A, Grom AA: Natural killer cell dysfunction is a distinguishing feature of systemic onset juvenile rheumatoid arthritis and macrophage activation syndrome. Arthritis Res Ther 2005;7:R30R37.

51 Wulffraat NM, Rijkers GT, Elst E, Brooimans R, Kuis W: Reduced perforin expression in systemic juvenile idiopathic arthritis is restored by autologous stem-cell transplantation. Rheumatology (Oxford) 2003;42: 375-379.

52 Hazen MM, Woodward AL, Hofmann I, Degar BA, Grom A, Filipovich AH, Binstadt BA: Mutations of the hemophagocytic lymphohistiocytosis-associated gene UNC13D in a patient with systemic juvenile idiopathic arthritis. Arthritis Rheum 2008;58:567-570.

53 Zhang K, Biroschak J, Glass DN, Thompson SD, Finkel T, Passo MH, Binstadt BA, Filipovich A, Grom AA: Macrophage activation syndrome in patients with systemic juvenile idiopathic arthritis is associated with MUNC13-4 polymorphisms. Arthritis Rheum 2008;58:2892-2896.
54 Grom AA: Natural killer cell dysfunction: a common pathway in systemic-onset juvenile rheumatoid arthritis, macrophage activation syndrome, and hemophagocytic lymphohistiocytosis? Arthritis Rheum 2004;50:689698.

55 Stepp SE, Mathew PA, Bennett M, de Saint Basile G, Kumar V: Perforin: more than just an effector molecule. Immunol Today 2000; 21:254-256.

56 Cortis E, Insalaco A: Macrophage activation syndrome in juvenile idiopathic arthritis. Acta Paediatr Suppl 2006;95:38-41.

57 Stephan JL, Kone-Paut I, Galambrun C, Mouy R, Bader-Meunier B, Prieur AM: Reactive haemophagocytic syndrome in children with inflammatory disorders. A retrospective study of 24 patients. Rheumatology (Oxford) 2001;40:1285-1292.

58 Hewagama A, Richardson B: The genetics and epigenetics of autoimmune diseases. J Autoimmun 2009;33:3-11.

59 Ingegnoli F, Fantini F, Favalli EG, Soldi A, Griffini S, Galbiati V, Meroni PL, Cugno M: Inflammatory and prothrombotic biomarkers in patients with rheumatoid arthritis: effects of tumor necrosis factor-alpha blockade. J Autoimmun 2008;31:175-179.

60 Henter JI, Horne A, Arico M, Egeler RM, Filipovich AH, Imashuku S, Ladisch S, McClain K, Webb D, Winiarski J, Janka G: HLH-2004: diagnostic and therapeutic guidelines for hemophagocytic lymphohistiocytosis. Pediatr Blood Cancer 2007;48: 124-131.

61 Coca A, Bundy KW, Marston B, Huggins J, Looney RJ: Macrophage activation syndrome: serological markers and treatment with anti-thymocyte globulin. Clin Immunol 2009; 132:10-18.

62 Vital EM, Emery P: The development of targeted therapies in rheumatoid arthritis. J Autoimmun 2008;31:219-227.

63 Sanchez-Pernaute O, Ospelt C, Neidhart M, Gay S: Epigenetic clues to rheumatoid arthritis. J Autoimmun 2008;30:12-20.

64 Pauley KM, Cha S, Chan EK: MicroRNA in autoimmunity and autoimmune diseases. J Autoimmun 2009;32:189-194.

65 Henter JI, Samuelsson-Horne A, Arico M, Egeler RM, Elinder G, Filipovich AH, Gadner $\mathrm{H}$, Imashuku S, Komp $\mathrm{D}$, Ladisch $\mathrm{S}$, Webb D, Janka G: Treatment of hemophagocytic lymphohistiocytosis with HLH-94 immunochemotherapy and bone marrow transplantation. Blood 2002;100:2367-2373.

66 Imashuku S, Kuriyama K, Sakai R, Nakao Y, Masuda S, Yasuda N, Kawano F, Yakushijin K, Miyagawa A, Nakao T, Teramura T, Tabata Y, Morimoto A, Hibi S: Treatment of Epstein-Barr virus-associated hemophagocytic lymphohistiocytosis (EBV-HLH) in young adults: a report from the HLH study center. Med Pediatr Oncol 2003;41:103-109. 
-67 Imashuku S, Kuriyama K, Teramura T, Ishii E, Kinugawa N, Kato M, Sako M, Hibi S: Requirement for etoposide in the treatment of Epstein-Barr virus-associated hemophagocytic lymphohistiocytosis. J Clin Oncol 2001;19:2665-2673.

68 Janka GE, Schneider EM: Modern management of children with haemophagocytic lymphohistiocytosis. Br J Haematol 2004; 124:4-14.

-69 Takahashi N, Chubachi A, Kume M, Hatano Y, Komatsuda A, Kawabata Y, Yanagiya N, Ichikawa Y, Miura AB, Miura I: A clinical analysis of 52 adult patients with hemophagocytic syndrome: the prognostic significance of the underlying diseases. Int J Hematol 2001;74:209-213.

70 Tsuda H: Hemophagocytic syndrome (HPS) in children and adults. Int J Hematol 1997;65: 215-226.

71 Imashuku S, Teramura T, Morimoto A, Hibi $S$ : Recent developments in the management of haemophagocytic lymphohistiocytosis. Expert Opin Pharmacother 2001;2:14371448.

-72 Kaito K, Kobayashi M, Katayama T, Otsubo H, Ogasawara Y, Sekita T, Saeki A, Sakamoto M, Nishiwaki K, Masuoka H, Shimada T, Yoshida M, Hosoya T: Prognostic factors of hemophagocytic syndrome in adults: analysis of 34 cases. Eur J Haematol 1997;59:247-253.

-73 Kumar MK, Suresh MK, Dalus D: Macrophage activation syndrome. J Assoc Physicians India 2006;54:238-240.

74 Lurati A, Terruzi B, Salmaso A, Demarco G, Pontikaki I, Gattinara M, Gerloni V, Fantini F: Macrophage activation syndrome (MAS) during anti-IL1 receptor therapy (anakinra) in a patient affected by systemic onset idiopathic juvenile arthritis (SOJIA): a report and review of the literature. Pediatr Rheumatol Online J 2005 3:79-85.

$>75$ Emmenegger U, Frey U, Reimers A, Fux C, Semela D, Cottagnoud P, Spaeth PJ, Neftel KA: Hyperferritinemia as indicator for intravenous immunoglobulin treatment in reactive macrophage activation syndromes. Am J Hematol 2001;68:4-10.

76 Burt RK, Testori A, Craig R, Cohen B, Suffit R, Barr W: Hematopoietic stem cell transplantation for autoimmune diseases: what have we learned? J Autoimmun 2008;30:116120.

77 Eisenberg R: Why can't we find a new treatment for SLE? J Autoimmun 2009;32:223230.

78 Marmont AM: Will hematopoietic stem cell transplantation cure human autoimmune diseases? J Autoimmun 2008;30:145-150.

79 Eraso R, Gedalia A, Espinoza LR: Methotrexate as a possible trigger of macrophage activation syndrome in systemic juvenile idiopathic arthritis. J Rheumatol 2002;29: 1104, author reply 1104-1105.
80 Chen HH, Kuo HC, Wang L, Yu HR, Shen JM, Kwang KP, Yang KD: Childhood macrophage activation syndrome differs from infection-associated hemophagocytosis syndrome in etiology and outcome in Taiwan. J Microbiol Immunol Infect 2007;40:265-271.

81 Imashuku S, Ueda I, Teramura T, Mori K, Morimoto A, Sako M, Ishii E: Occurrence of haemophagocytic lymphohistiocytosis at less than 1 year of age: analysis of 96 patients. Eur J Pediatr 2005;164:315-319.

82 Kuzmanova SI: The macrophage activation syndrome: a new entity, a potentially fatal complication of rheumatic disorders. Folia Med (Plovdiv) 2005;47:21-25.

83 Ozawa K, Sato K, Oh I, Ozaki K, Uchibori R, Obara Y, Kikuchi Y, Ito T, Okada T, Urabe M, Mizukami H, Kume A: Cell and gene therapy using mesenchymal stem cells (MSCS). J Autoimmun 2008;30:121-127.

84 Invernizzi P: Future directions in genetic for autoimmune diseases. J Autoimmun 2009; 33:1-2.

85 Kobayashi I, Yamada M, Kawamura N, Kobayashi R, Okano M, Kobayashi K: Plateletspecific hemophagocytosis in a patient with juvenile dermatomyositis. Acta Paediatr 2000;89:617-619.

86 Kaneko K, Takahashi K, Fujiwara S, Maruyama T, Obinata K: Kawasaki disease followed by haemophagocytic syndrome. Eur J Pediatr 1998;157:610-611.

$>87$ Muise A, Tallett SE, Silverman ED: Are children with Kawasaki disease and prolonged fever at risk for macrophage activation syndrome? Pediatrics 2003;112:e495.

88 Javier RM, Sibilia J, Offner C, Albert A, Kuntz JL: Macrophage activation syndrome in lupus (in French). Rev Rhum Ed Fr 1993; 60:831-835

89 McCann LJ, Hasson N, Pilkington CA: Macrophage activation syndrome as an early presentation of lupus. J Rheumatol 2006;33: 438-440.

90 Takahashi K, Kumakura S, Ishikura H, Murakawa Y, Yamauchi Y, Kobayashi S: Reactive hemophagocytosis in systemic lupus erythematosus. Intern Med 1998;37:550-553.

91 Tsuji T, Ohno S, Ishigatsubo Y: Liver manifestations in systemic lupus erythematosus: high incidence of hemophagocytic syndrome. J Rheumatol 2002;29:1576-1577.

-92 Wong KF, Hui PK, Chan JK, Chan YW, Ha SY: The acute lupus hemophagocytic syndrome. Ann Intern Med 1991;114:387-390.

-93 Pamuk ON, Pamuk GE, Usta U, Cakir N: Hemophagocytic syndrome in one patient with adult-onset Still's disease. Presentation with febrile neutropenia. Clin Rheumatol 2007; 26:797-800.

$>94$ Lou YJ, Jin J, Mai WY: Ankylosing spondylitis presenting with macrophage activation syndrome. Clin Rheumatol 2007;26:19291930.
\$95 Reiner AP, Spivak JL: Hematophagic histiocytosis. A report of 23 new patients and a review of the literature. Medicine (Baltimore) 1988;67:369-388.

96 Chauveau E, Terrier F, Casassus-Buihle D, Moncoucy X, Oddes B: Macrophage activation syndrome after treatment with infliximab for fistulated Crohn's disease. Presse Med 2005;34:583-584.

97 James DG, Stone CD, Wang HLL, Stenson WF: Reactive hemphagocytic syndrome complicating the treatment of inflammatory bowel disease. Inflamm Bowel Dis 2006;12:573-580.

$>98$ Davies SV, Dean JD, Wardrop CA, Jones JH: Epstein-Barr virus-associated haemophagocytic syndrome in a patient with juvenile chronic arthritis. Br J Rheumatol 1994;33:495-497.

99 de Benedetti F, Pignatti P, Massa M, Sartirana P, Ravelli A, Cassani G, Corti A, Martini A: Soluble tumour necrosis factor receptor levels reflect coagulation abnormalities in systemic juvenile chronic arthritis. Br J Rheumatol 1997;36:581-588.

100 Fishman D, Rooney M, Woo P: Successful management of reactive haemophagocytic syndrome in systemic-onset juvenile chronic arthritis. Br J Rheumatol 1995;34: 888 .

101 Gianella S, Schaer DJ, Schwarz U, Kurrer M, Heppner FL, Fehr J, Seebach JD: Retinal microangiopathy and rapidly fatal cerebral edema in a patient with adult-onset Still's disease and concurrent macrophage activation syndrome. Am J Hematol 2008;83: 424-427.

102 Grom AA, Passo M: Macrophage activation syndrome in systemic juvenile rheumatoid arthritis. J Pediatr 1996;129:630-632.

103 Mouy R, Stephan JL, Pillet P, Haddad E, Hubert P, Prieur AM: Efficacy of cyclosporine $\mathrm{A}$ in the treatment of macrophage activation syndrome in juvenile arthritis: report of five cases. J Pediatr 1996;129:750754.

104 Prieur AM, Stephan JL: Macrophage activation syndrome in rheumatic diseases in children (in French). Rev Rhum Ed Fr 1994; 61:447-451.

105 Ravelli A, De Benedetti F, Viola S, Martini A: Macrophage activation syndrome in systemic juvenile rheumatoid arthritis successfully treated with cyclosporine. J Pediatr 1996;128:275-278.

106 Stern A, Riley R, Buckley L: Worsening of macrophage activation syndrome in a patient with adult onset Still's disease after initiation of etanercept therapy. J Clin Rheumatol 2001;7:252-256.

107 Tapia Ceballos L, Picazo Angelin B, Romero Sanchez J, Diaz Cabrera R, Romero Narbona F, Romero Gonzalez J: Macrophage activation syndrome secondary to Still disease (in Spanish). An Esp Pediatr 1999;51: 194-196. 
108 Tristano AG: Macrophage activation syndrome associated with systemic onset juvenile rheumatoid arthritis. South Med J 2006;99:786-787.

109 Tristano AG, Casanova-Escalona L, Torres A, Rodriguez MA: Macrophage activation syndrome in a patient with systemic onset rheumatoid arthritis: rescue with intravenous immunoglobulin therapy. J Clin Rheumatol 2003;9:253-258.

- 110 Horne A, Ramme KG, Rudd E, Zheng C, Wali Y, al-Lamki Z, Gurgey A, Yalman N, Nordenskjold M, Henter JI: Characterization of PRF1, STX11 and UNC13D genotype-phenotype correlations in familial hemophagocytic lymphohistiocytosis. Br J Haematol 2008;143:75-83.

- 111 Rudd E, Bryceson YT, Zheng C, Edner J, Wood SM, Ramme K, Gavhed S, Gurgey A, Hellebostad M, Bechensteen AG, Ljunggren HG, Fadeel B, Nordenskjold M, Henter JI: Spectrum, and clinical and functional implications of UNC13D mutations in familial haemophagocytic lymphohistiocytosis. J Med Genet 2008;45:134-141.

- 112 Mehdizadeh M, Zamani G: Griscelli syndrome: a case report. Pediatr Hematol Oncol 2007;24:525-529.

-113 Andre N, Roquelaure B, Caillez M, Chrestian M, Moncla A, Blanco-Betancourt C, Schiff C: Macrophage activation syndrome mimicking life-threatening infection in a patient with variable immunodeficiency, centromeric instability, and facial anomalies. Pediatrics 2004;114:1127.

- 114 Aiuti A, Cattaneo F, Galimberti S, Benninghoff U, Cassani B, Callegaro L, Scaramuzza S, Andolfi G, Mirolo M, Brigida I, Tabucchi A, Carlucci F, Eibl M, Aker M, Slavin S, Al-Mousa H, Al Ghonaium A, Ferster A, Duppenthaler A, Notarangelo L, Wintergerst U, Buckley RH, Bregni M, Marktel S, Valsecchi MG, Rossi P, Ciceri F, Miniero R, Bordignon C, Roncarolo MG: Gene therapy for immunodeficiency due to adenosine deaminase deficiency. N Engl J Med 2009;360:447-458.

- 115 Rubin CM, Burke BA, McKenna RW, McClain KL, White JG, Nesbit ME Jr, Filipovich $\mathrm{AH}$ : The accelerated phase of ChediakHigashi syndrome. An expression of the virus-associated hemophagocytic syndrome? Cancer 1985;56:524-530.

- 116 Enders A, Zieger B, Schwarz K, Yoshimi A, Speckmann C, Knoepfle EM, Kontny U, Muller C, Nurden A, Rohr J, Henschen M, Pannicke U, Niemeyer C, Nurden P, Ehl S: Lethal hemophagocytic lymphohistiocytosis in Hermansky-Pudlak syndrome type II. Blood 2006;108:81-87.

- 117 Silverman ED, Miller JJ 3rd, Bernstein B, Shafai T: Consumption coagulopathy associated with systemic juvenile rheumatoid arthritis. J Pediatr 1983;103:872-876.
118 Jacobs JC, Gorin LJ, Hanissian AS, Simon JL, Smithwick EM, Sullivan D: Consumption coagulopathy after gold therapy for JRA. J Pediatr 1984;105:674-675.

119 Ravelli A, Caria MC, Buratti S, Malattia C, Temporini F, Martini A: Methotrexate as a possible trigger of macrophage activation syndrome in systemic juvenile idiopathic arthritis. J Rheumatol 2001;28:865-867.

120 Sterba G, Rodriguez C, Sifontes S, Vigilanza P: Macrophage activation syndrome due to methotrexate in a 12-year-old boy with dermatomyositis. J Rheumatol 2004;31: 1014-1015, author reply 1015.

121 Barash J, Cooper M, Tauber Z: Hepatic, cutaneous and hematologic manifestations in juvenile chronic arthritis. Clin Exp Rheumatol 1991;9:541-543.

122 Olgar S, Ertugrul T, Devecioglu O, Nisli K, Omeroglu RE: Does red-man reaction stimulate macrophage activation syndrome in children with systemic juvenile idiopathic arthritis? J Rheumatol 2007;34:24912494.

-123 Brinkman DM, de Kleer IM, ten Cate R, van Rossum MA, Bekkering WP, Fasth A, van Tol MJ, Kuis W, Wulffraat NM, Vossen JM: Autologous stem cell transplantation in children with severe progressive systemic or polyarticular juvenile idiopathic arthritis: long-term follow-up of a prospective clinical trial. Arthritis Rheum 2007;56: 2410-2421.

124 Sreedharan A, Bowyer S, Wallace CA, Robertson MJ, Schmidt K, Woolfrey AE, Nelson RP Jr: Macrophage activation syndrome and other systemic inflammatory conditions after BMT. Bone Marrow Transplant 2006;37:629-634.

125 ten Cate R, Brinkman DM, van Rossum MA, Lankester AC, Bredius RG, Egeler MR, van Tol MJ, Vossen JM: Macrophage activation syndrome after autologous stem cell transplantation for systemic juvenile idiopathic arthritis. Eur J Pediatr 2002;161 686-686.

$>126$ Goulet O, Girot R, Maier-Redelsperger M, Bougle D, Virelizier JL, Ricour C: Hematologic disorders following prolonged use of intravenous fat emulsions in children. JPEN J Parenter Enteral Nutr 1986;10:284288.

-127 Soult Rubio JA, Garcia Bernabeu V, Sanchez Alvarez MJ, Munoz Saez M, Lopez Castilla JD, Tovaruela Santos A: Macrophage activation syndrome: a diagnostic challenge (in Spanish). An Esp Pediatr 2002; 56 : 165-167.

128 Lecointe D, Fabre M, Habes D, Mielot F, Bernard O, Nordmann P: Macrophage activation syndrome in primary human herpes virus- 6 infection: a rare condition after liver transplantation in infants (in French). Gastroenterol Clin Biol 2000;24:12271228.
129 Russo RA, Rosenzweig SD, Katsicas MM: Hepatitis A-associated macrophage activation syndrome in children with systemic juvenile idiopathic arthritis: report of 2 cases. J Rheumatol 2008;35:166-168.

130 Seidel MG, Kastner U, Minkov M, Gadner H: IVIG treatment of adenovirus infectionassociated macrophage activation syndrome in a two-year-old boy: case report and review of the literature. Pediatr Hematol Oncol 2003;20:445-451.

-131 Francois B, Clavel M, Trimoreau F, Desachy A, Slaouti P, Gastinne H: Pancytopenia and pulmonary tuberculosis. Significance of a hemophagocytic syndrome (in French). Rev Mal Respir 1998;15:668-670.

132 Gagnaire MH, Galambrun C, Stephan JL: Hemophagocytic syndrome: a misleading complication of visceral leishmaniasis in children - a series of 12 cases. Pediatrics 2000;106:E58.

133 Algayres JP, Daly JP, Oddes B, Valmary J, Halna du Fretay X, Maurel C, Thomas A, Chabierski M, Larroque P, Laverdant C: Hepatic manifestations in Still's disease (in French). Ann Med Interne (Paris) 1988;139: 476-481.

134 Balduck N, Otten J, Verbruggen L, Bougatef A, Ramet J, Piepsz A: Sudden death of a child with juvenile chronic arthritis, probably due to indomethacin. Eur J Pediatr 1987; 146:620

135 Bray VJ, Singleton JD: Disseminated intravascular coagulation in Still's disease. Semin Arthritis Rheum 1994;24:222-229.

136 Cuende E, Vesga JC, Perez LB, Ardanaz MT, Guinea J: Macrophage activation syndrome as the initial manifestation of systemic onset juvenile idiopathic arthritis. Clin Exp Rheumatol 2001;19:764-765.

137 Heaton DC, Moller PW: Still's disease associated with Coxsackie infection and haemophagocytic syndrome. Ann Rheum Dis 1985;44:341-344.

138 Hertzberger-ten Cate R, Cats A: Toxicity of sulfasalazine in systemic juvenile chronic arthritis. Clin Exp Rheumatol 1991;9:8588.

139 Kornreich H, Malouf NN, Hanson V: Acute hepatic dysfunction in juvenile rheumatoid arthritis. J Pediatr 1971;79:27-35.

140 Makela AL, Lang H, Korpela P: Toxic encephalopathy with hyperammonaemia during high-dose salicylate therapy. Acta Neurol Scand 1980;61:146-156.

141 Morris JA, Adamson AR, Holt PJ, Davson J: Still's disease and the virus-associated haemophagocytic syndrome. Ann Rheum Dis 1985;44:349-353.

142 Pinedo HM, van de Putte LB, Loeliger EA: Salicylate-induced consumption coagulopathy. Ann Rheum Dis 1973;32:66-68.

143 Prahalad S, Bove KE, Dickens D, Lovell DJ, Grom AA: Etanercept in the treatment of macrophage activation syndrome. J Rheumatol 2001;28:2120-2124. 
144 Rich RR, Johnson JS: Salicylate hepatotoxicity in patients with juvenile rheumatoid arthritis. Arthritis Rheum 1973;16:1-9.

145 Sbarbaro JA, Bennett RM: Aspirin hepatotoxicity and disseminated intravascular coagulation. Ann Intern Med 1977;86:183185.

146 Ulshen MH, Grand RJ, Crain JD, Gelfand EW: Hepatoxicity with encephalopathy associated with aspirin therapy in rheumatoid arthritis. J Pediatr 1978;93:1034-1037.
147 You CR, Kim HR, Yoon CH, Lee SH, Park SH, Kim HY: Macrophage activation syndrome in juvenile rheumatoid arthritis successfully treated with cyclosporine A: a case report. J Korean Med Sci 2006;21:11241127.

-148 Henter JI, Arico M, Egeler RM, Elinder G, Favara BE, Filipovich AH, Gadner $\mathrm{H}$ Imashuku S, Janka-Schaub G, Komp D, Ladisch S, Webb D: HLH-94: a treatment protocol for hemophagocytic lymphohistiocytosis. HLH Study Group of the Histiocyte Society. Med Pediatr Oncol 1997;28:342347.

149 Matsumoto Y, Naniwa D, Banno S, Sugiura Y: The efficacy of therapeutic plasmapheresis for the treatment of fatal hemophagocytic syndrome: two case reports. Ther Apher 1998;2:300-304.
50 Prendiville JS, Tucker LB, Cabral DA, Crawford RI: A pruritic linear urticarial rash, fever, and systemic inflammatory disease in five adolescents: adult-onset Still disease or systemic juvenile idiopathic arthritis sine arthritis? Pediatr Dermatol 2004;21:580-588.

151 Sproat LO, Pantanowitz L, Lu CM, Dezube BJ: Human immunodeficiency virus-associated hemophagocytosis with iron-deficiency anemia and massive splenomegaly. Clin Infect Dis 2003;37:e170-e173. 